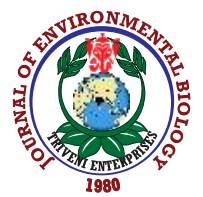

\title{
Identification, characterization and mapping of honey bee flora of Al-Baha region of Saudi Arabia
}

\author{
A.A. Al-Ghamdi', A. Al-Khulaidi ${ }^{2,3}$, N.A. Al-Sagheer ${ }^{23,}$, A. Nuru' and Y. Tadesse ${ }^{1}$ \\ 'Department of Plant Protection, College of Food and Agriculture Science, King Saud University, Riyadh, 11451, SaudiA Arabia \\ ${ }^{2}$ Department of Biology, College of Science and Arts, Al-Baha University, Al Baha, 65527, SaudiArabia \\ ${ }^{3}$ Agricultural Research and Extension Authority, Dhamar, 87148, Yemen \\ *Corresponding Author Email : alsaghiernageeb@gmail.com
}

Paper received: 14.06 .2019

Revised received: 25.10 .2019

Accepted: 13.12 .2019

\section{Abstract}

Aim: The study aimed to identify and document major honey bee flora, their blooming seasons(floral calendar), density and frequency, beekeeping potential areas, and place radius for the major bee flora of the Al-Baha region.

Methodology: To identify the honey bee flora of al-Baha region, 420 quadrates were established in different seasons and ecological zones. Plants as honey bee forages were identified through observation of the foraging of honey bees on the flowers for nectar or/and pollen. The density and frequency of each plant was calculated, density and radius maps for major honey bee plants were made using the Arc-Map. Canonical Correspondence Analysis (CCA) was carried out for major honey bee plants using MVSP software.

Results: The results showed that more than 550 species of flowering plants were recorded in the study areas, of which 204 plant species belonging to 58 families were identified as honey

550 species of flowering plants recorded of which 204 plant species belonging to 58 families were identified as honeybee flora

Dominant honeybee flora with their frequency (freq.)

Acacia origena (Freq.28), Acacia ehrenbergiana (Freq.23), Acacia asak (Freq.23), Blepharisedulis (Freq.21), Acacia tortilis (Freq.20), Ziziphusspina-christi (Freq.20), Acacia etbaica (Freq.13), Lavanduladentate (Freq.23), Hypoestesforskaolii (Freq.6).

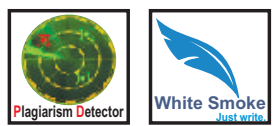

bee plants. However, only 9 species were found to be an important source of major honeys in the region. The largest number (13\%) of honey bee plants was recorded for the family Asteraceae, followed by Lamiaceae, Euphorbiaceae, Fabaceae and Mimosaceae each with 13 (6.4\%), 11 (5.4\%), 11 (5.4\%) and $10(4.9 \%)$ plants, respectively. Each of the remaining families had 1 to 8 species.

Interpretation: The radius maps, as well as the blooming periods of honey bee flora will guide beekeepers to move their colonies during the peak flowering periods.

Key words: Al-Baha region, Canonical Correspondence Analysis, Ecological zones, Honey bee flora, Nectar, Pollen grains

How to cite : A.A. Al-Ghamdi, A. Al-Khulaidi, N.A. Al-Sagheer, A. Nuru and Y. Tadesse: Identification, characterization and mapping of honey bee flora of Al-Baha region of Saudi Arabia. . J. Environ. Biol., 41, 613-622 (2020). 


\section{Introduction}

Bees collect and consume nectar and pollens from a wide variety of flowering plants to gain protein, carbohydrates, minerals and vitamins (Amanda et al., 2010). While bees visiting plants they pollinate the flowers, thereby helping to increase fruit and seed-setting (Dukku, 2013). So insect pollination of wild plants and agricultural crops is a significant ecosystem service (Bhalchandra et al., 2014). A good apiary site is the one where nectar and pollen source plants are grow in relatively large members with long blooming season. If the apiary site is not suitable, knowledge and technologies by themselves do not make beekeeping successful. Beekeeping is more dependent on the suitability of an area than any other livestock production (Nuru, 2018). The suitability of an apiary mainly depends on types, density and distribution of important honey bee flora. Many honey plants are used in traditional medicine and pharmaceutical production (Behera et al., 2014). Plants species that provide nectar and/or pollen to honey bees are called honey bee flora.

Since, all flowering plants are not honey bee plants and all bee plants are not also equally important as a source of nectar and pollen to the bees, it is very important to characterize the general vegetation and honey bee floral conditions of a given area (Nuru et al., 2017). In this regard, Crane (1990) reported that only $16 \%$ of the world's flowering plant species contribute to honey bees as food sources and only $1.6 \%$ of the world's honey bee plants are the source of most of the world's honeys. This generally indicates that, for every geographical region there are important honey source plants and it is essential to characterize and map them according to their degree of importance for their better utilization in honey production.

Identification and mapping of honey source plants are very important for the selection of suitable apiary sites and also to determine the honey bee colony carrying capacity of an area (Beyene and Hiwot, 2015). Moreover, characterization and mapping of bee forage plants are reported to be useful to guide beekeepers to timely migrate their honey bee colonies to exploit bee forage resources available at different ecologies and seasons (Nuru et al., 2017). Because of suitable climatic conditions and growing of multipurpose honey bee flora, as well as variation in the topography, Al-Baha region is relatively one of the potential areas for beekeeping in Saudi Arabia (Al-Aklabi et al., 2016; Al-Khulaidi et al., 2016 and 2018). As a result, beekeeping is widely practiced and it is an important part of the livelihoods of many rural communities of this region. Because of the existence of very contrast ecologies in a very close proximity, beekeepers in Al-Baha region commonly migrate their bee colonies primarily during the flowering periods of some major honey source plants (Nuru et al., 2014; Al-Ghamdi et al., 2014).

However, information on the types of bee flora, type of food sources (pollen and/or nectar) and their flowering periods are not well documented. Several authors (Sammouda et al., 2013; Al-Ghamdi, et al., 2014; Nuru et al., 2016a, Al-Ghamdi, et al., 2016; Nuru et al., 2017; Al-Baggar, 2019) have tried to identify some of the major honey bee flora of the region. These studies were not exhaustive to address all the honey bee flora of the region and the area coverage was limited to only certain valleys. Moreover, these studies mainly focused on the identification of species without mapping their spatial and temporal distributions to guide the movements of bee colonies across the Al-Baha region. For characterization of plants as honey bee flora it is important to know the value of the plant as dominant pollen or nectar or both sources in order to manage bee colonies according to floral resources. Plants with a good source of pollen grains serve as a source of protein and minerals and are useful for population build-up (Akratanakul, 1990; Kumar et al., 2016), while plants with good source of nectar are useful for honey production. With this general background, the current study aimed at identifying, characterize and mapping the honey bee flora of the Al-Baha region and guide beekeepers to move their colonies and utilize the bee floral resources available at different seasons and ecologies.

\section{Materials and Methods}

The study area (Al-Baha region) is located in the South West part of Saudi Arabia. The region encompasses very diverse physiographic features: mountain peaks, highland plateaus and moderate to steep slope escarpments, valleys and lowland plains with an altitude range of 300-2565 m above sea level (Fig. 1). Compared to other parts of the country, this region receives relatively moderate rainfall ranging from 100$250 \mathrm{~mm}$ per annum. Because of its diverse ecologies and relatively moderate climates, the region is characterized by relatively high plant diversity.

Sampling, identification and characterization: To identify and characterize the honey bee flora of Al-Baha region, 420 quadrates were established during different seasons and in different ecological zones of the study area. The quadrates were established following transect sampling procedures and each quadrate consisted of $25 \times 25 \mathrm{~m}$. Each plant species in the quadrates were recorded with their respective coordinate. The species name and their families were identified by taxonomists using herbarium specimens and photographs taken during the inventory. Plants as bee forage were determined through careful observation of the foraging behaviors of honeybees on the flower for nectar or/and pollens. In addition, the flowering period of each plant was determined through close monitoring of the onset and end of flowering at different seasons and ecologies. The relative frequency of each bee flora was calculated by determining the proportion of the quadrates in which that particular species occurred.

$$
\begin{array}{r}
\text { Relative frequency }=\begin{array}{r}
\text { Number of sample plot in which a } \\
\text { bee flora species occurred } x 100
\end{array} \\
\text { Total sample plots surveyed }
\end{array}
$$

Further, the density per hectare of each plant was calculated from the density of each plant per quadrate. In 
addition, the percentage of frequency of each plant was obtained from the proportion or percentage of quadrates in which the given species occurred.

Mapping of distribution of bee forage plants: The radius map was prepared based on the coordinates and density of each honey bee plant per quadrate using Arc-Map. Each radius map depicts both actual distribution (density) of each honey bee plant and also the vicinity radius placed within $3 \mathrm{~km}$ range from the density radius following Beekman and Ratnieks (2000) procedures. To understand the main factors determining the distribution of bee plants and also to analyse the associations between the major honey bee plant species and environmental variables (altitude and rainfall), Canonical Correspondence Analysis was conducted using Multivariate Statistical Packages (MVSP) version 3. The relative suitability of specific study areas was assessed based on the number of bee plant species growing per given areas. Accordingly, the overlapped distribution map of major bee plant species was prepared.

\section{Results and Discussion}

In general, from 420 quadrates 550 plant species were recorded of which 204 plant species belonging to 58 families were identified as honey bee plants (Table 1). Similarly, Crane (1990) reported that of the total world flowering plants only $16 \%$ serve as sources of nectar or/and pollens to honey bees. Among 204 bee plant species, 89 were identified as sources of both nectar and pollens, 60 as a source of nectar while 55 of them were identified only as source pollens to bees. The average frequency of the species was $4.51 \%$ and varied from $0.24-27.62 \%$ (Table 2 ). The

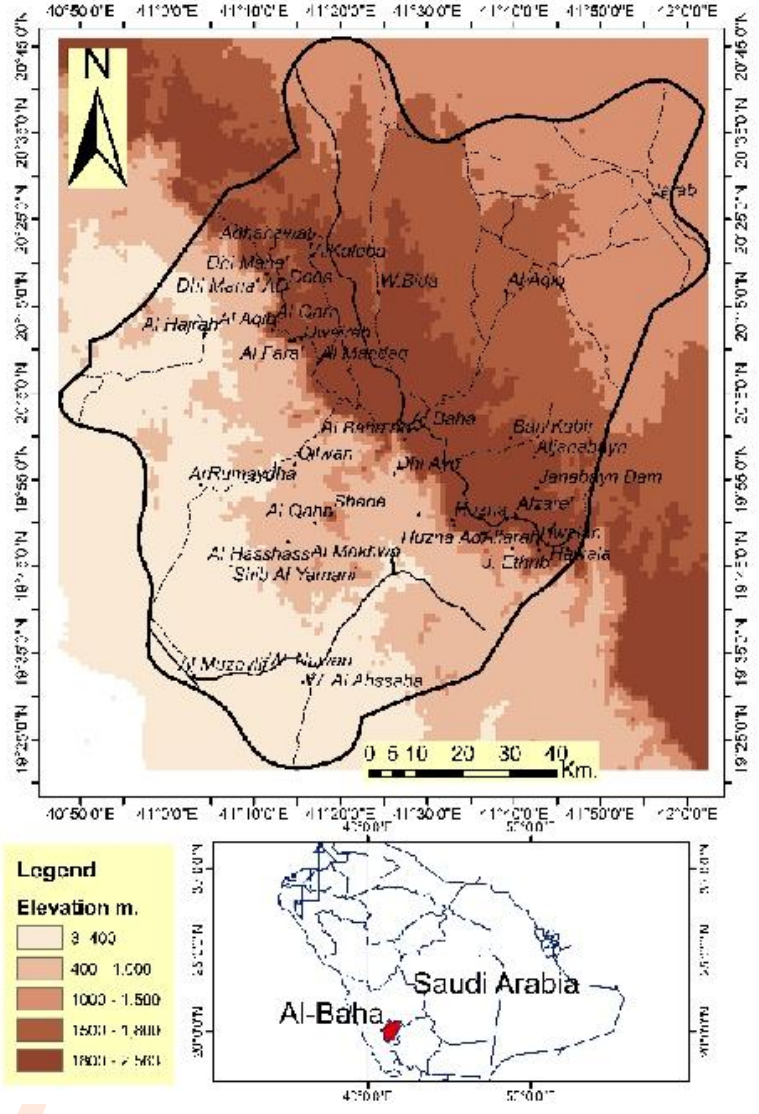

Fig. 1: Location of the study area with altitude ranges.

Table 1: Plant families with relatively high number of bee forage species

\begin{tabular}{llllll}
\hline Family & $\begin{array}{l}\text { No. of bee } \\
\text { plant species }\end{array}$ & Family & $\begin{array}{l}\text { No. of bee } \\
\text { plant species }\end{array}$ & Family & $\begin{array}{l}\text { No. of bee } \\
\text { plant species }\end{array}$ \\
\hline Asteraceae & 26 & Boraginaceae & 3 & Cactaceae & 1 \\
Lamiaceae & 13 & Caesalpiniaceae & 3 & Caryophyllaceae & 1 \\
Fabaceae & 11 & Convolvulaceae & 3 & Celastraceae & 1 \\
Euphorbiaceae & 10 & Portulacaceae & 3 & Crassulaceae & 1 \\
Mimosaceae & 10 & Rhamnaceae & 3 & Cucurbitaceae & 1 \\
Acanthaceae & 8 & Amaranthaceae & 2 & Ericaceae & 1 \\
Chenopodiaceae & 6 & Arecaceae & 2 & Iridaceae & 1 \\
Geraniaceae & 6 & Cleomaceae & 2 & Moringaceae & 1 \\
Solanaceae & 6 & Combretaceae & 2 & Ochnaceae & 1 \\
Tiliaceae & 6 & Ebenaceae & 2 & Oxalidaceae & 1 \\
Brassicaceae & 5 & Loganiaceae & 2 & Polygonaceae & 1 \\
Capparaceae & 5 & Oleaceae & 2 & Ranunculaceae & 1 \\
Malvaceae & 5 & Poaceae (Graminea) & 2 & Rubaceae & 1 \\
Papaveraceae & 5 & Resedaceae & 2 & Sapindaceae & 1 \\
Polygalaceae & 5 & Tamaricaceae & 2 & Scrophulariaceae & 1 \\
Zygophyllaceae & 5 & Aizoaceae & 1 & Ulmaceae & 1 \\
Aloeaceae & 4 & Anacardiaceae & 1 & Verbenaceae & 1 \\
Burseraceae & 4 & Apiaceae & 1 & Xanthorrhoeaceae & 1 \\
Plantaginaceae & 4 & Asparagaceae & 1 & & \\
Apocynaceae & 3 & & & &
\end{tabular}




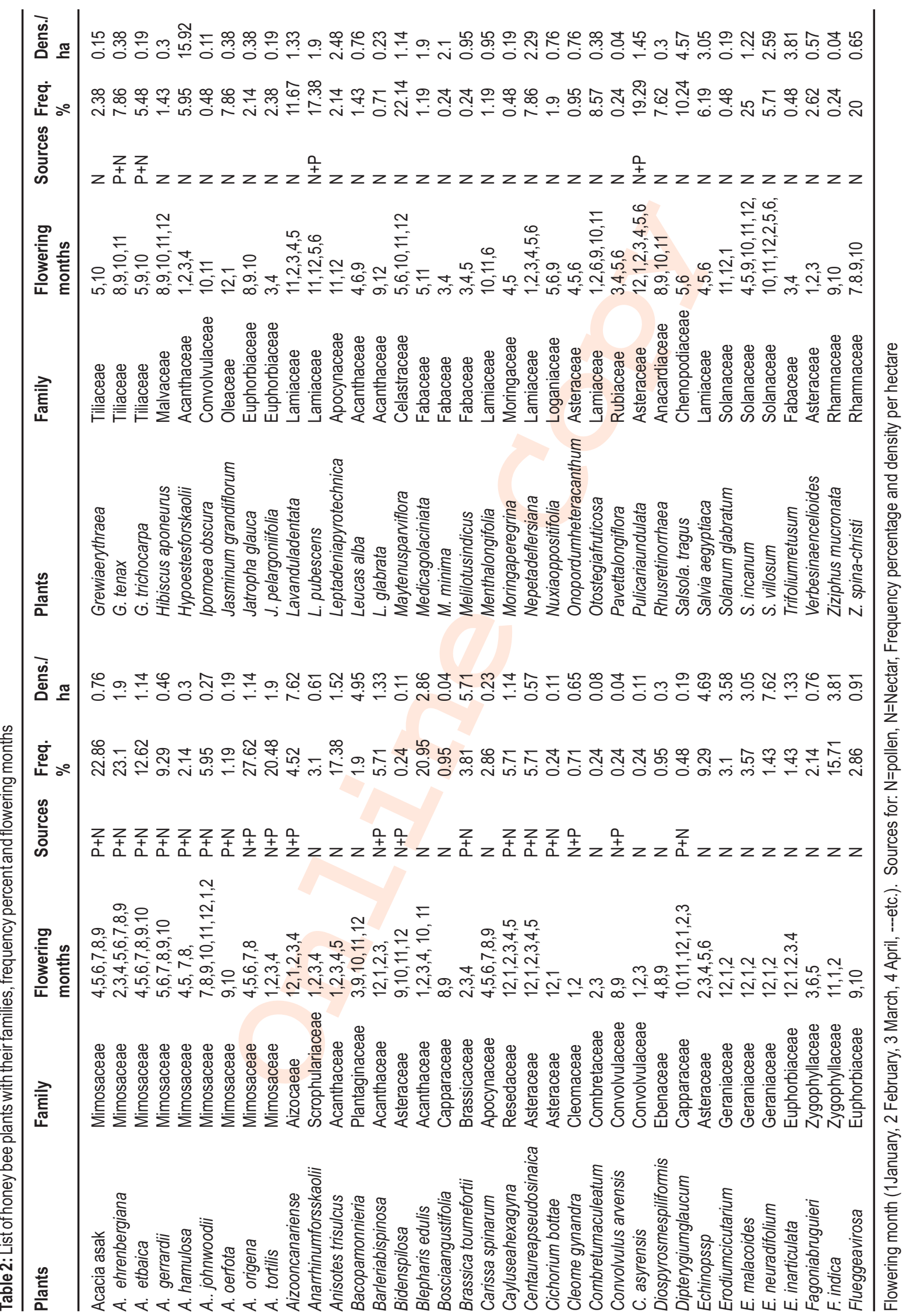


detailed list of the species with their families, their flowering periods, the types of floral rewards to the bees (pollen and/or nectar), frequency percentages and density per hectare of major 72 honey plants are shown in Table 2. Based on their frequencies and distribution, the most abundant bee flora species of the region with more than $20 \%$ frequency were only 13 species which included Acacia origena, Dodonaea viscosa, Solanum incanum, Olea europaea, Cenchrus ciliaris, Aerva javanica, Psiadia punctulata, Acacia ehrenbergiana, Acacia asak, Maytenus parviflora, Blepharis edulis, Acacia tortilis and Ziziphusspinachristi, with 28, 26, 25, 24, 24, 24, 24, 23, 23, 22, 21, 20 and 20\% frequencies, respectively (Fig. 2).

The average density of identified bee plants was very low (0.4 per hectare) with a range of $0.04-16.72$ per hectare. The data record showed that more than $70 \%$ of the identified bee plant species had less than 1 density per hectare (Table 2). Similarly, the occurrence of low plant density, frequency and diversity have been reported for the region (Nuru et al., 2017; Al-Khulaidi et al., 2018; Al-Zandi et al., 2018) which could be due to factors such as human interferences, recurrent drought and associated climate changes. Similarly, El-Juhany (2009) and Hall et al. (2010) reported similar contributing factors for decrease in several plant species in the region. Plant families with high numbers of bee plant species were Asteraceae with 26 species, Lamiaceae with 13 species, Fabaceae with 11 species, Euphorbiaceae and Mimosaceae with 10 species each. However, most of the bee flora families recorded in the study area were represented only by one bee flora species (Table 1). Similar families with high number of plant species were also reported (Nuru et al., 2017; Al-Zandi et al., 2018). The identified bee plants were categorized into grasses (2), herbs (120), shrubs (31) and trees (51) species. The flowering periods of bee plants were fairly distributed throughout the year, but mainly concentrated during spring and summer seasons (Table 2) which is associated with rainfall patterns of the region. The spatial distributions of major (nine) honey bee plants of the region per quadrate are shown in Fig. $3 \mathrm{~A}-\mathrm{I}$. The maps indicate that the density and distribution of $A$. asak, $A$. etbaica, Hypoestes forskalei and Lavandul adentata were relatively low, while the density and distribution of $A$. ehrenbergiana, A. origena, $A$. tortilis, Blepharis edulis, Ziziphus spina-christi were relatively high covering a wide range of ecologies. Moreover, the honey bee plants such as $A$. origena, Hypoestes forskalei and Lavandula dentata were restricted to high altitude areas, while $A$. tortilis, $A$. ehrenbergiana, Blepharis edulis, $A$. asak and Ziziphus spinachristi were distributed in low land to mid altitude areas (Fig. 3A-I).

According to Canonical Correspondence Analysis, three distinct cluster groups were observed (Fig. 4). The first group was positively correlated with altitude and rainfall, while the second and the third groups were negatively correlated with the altitude and rainfall. Hence, $A$. origena, $H$. forskaolii and $L$. dentata formed distinct group (1) and were associated with relatively high altitude $(1700$ and $2400 \mathrm{~m}$ ) areas with better rainfall conditions. On other hand, plant species such as $A$. tortilis and $A$. ehrenbergiana formed a separate group (2) and were mainly distributed in low land altitudes with little rainfall conditions. Bee plant species such as Blepharis edulis, Ziziphusspina-christi, $A$. etbaica and $A$. asak formed other distinct group (3) and were found in mid altitude $(200-1100 \mathrm{~m})$ areas with relatively medium rainfall. Despite the species being in same group, Blepharis edulis and Ziziphus spina-christi were mostly found in the beds of valleys (Wadis), while $A$. asak preferred to grow on medium to steep slope rocky lands, A. etbaica mostly grew in eastern aspects of the study area, because of this, the association between the species was not

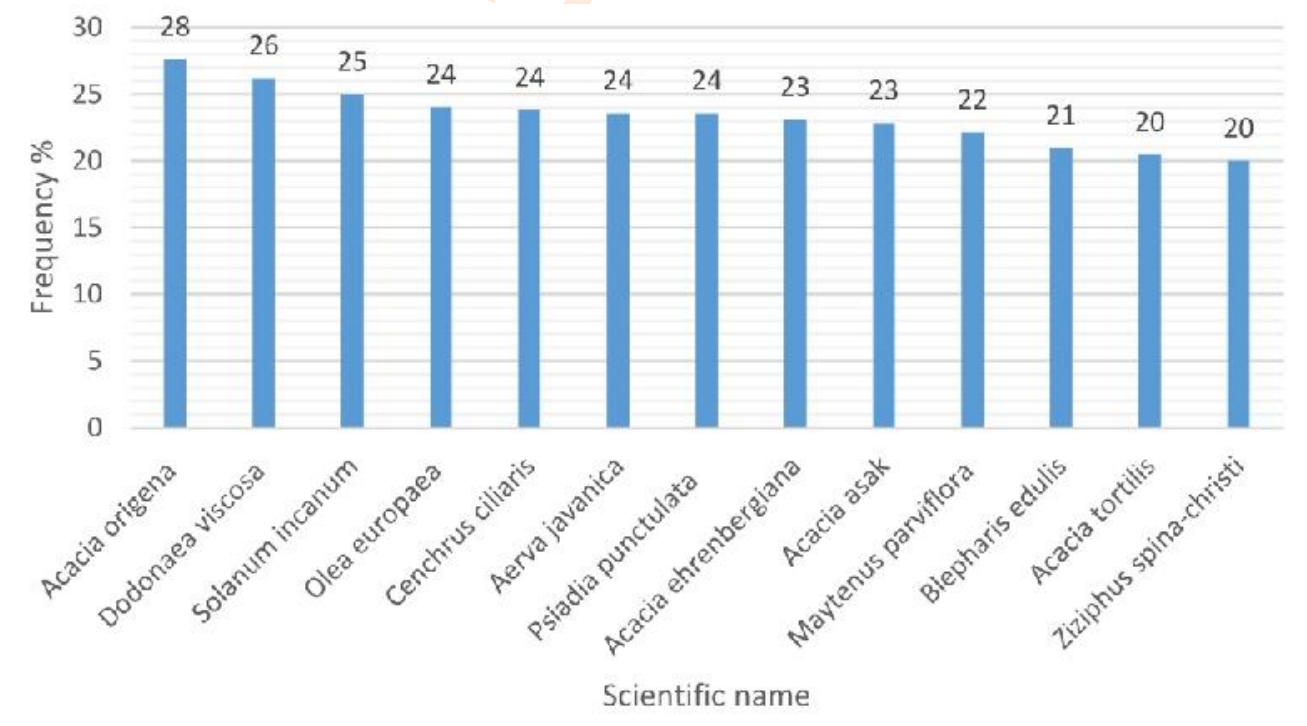

Fig. 2: Frequency percentages and density per hectare of 72 honey plants. 

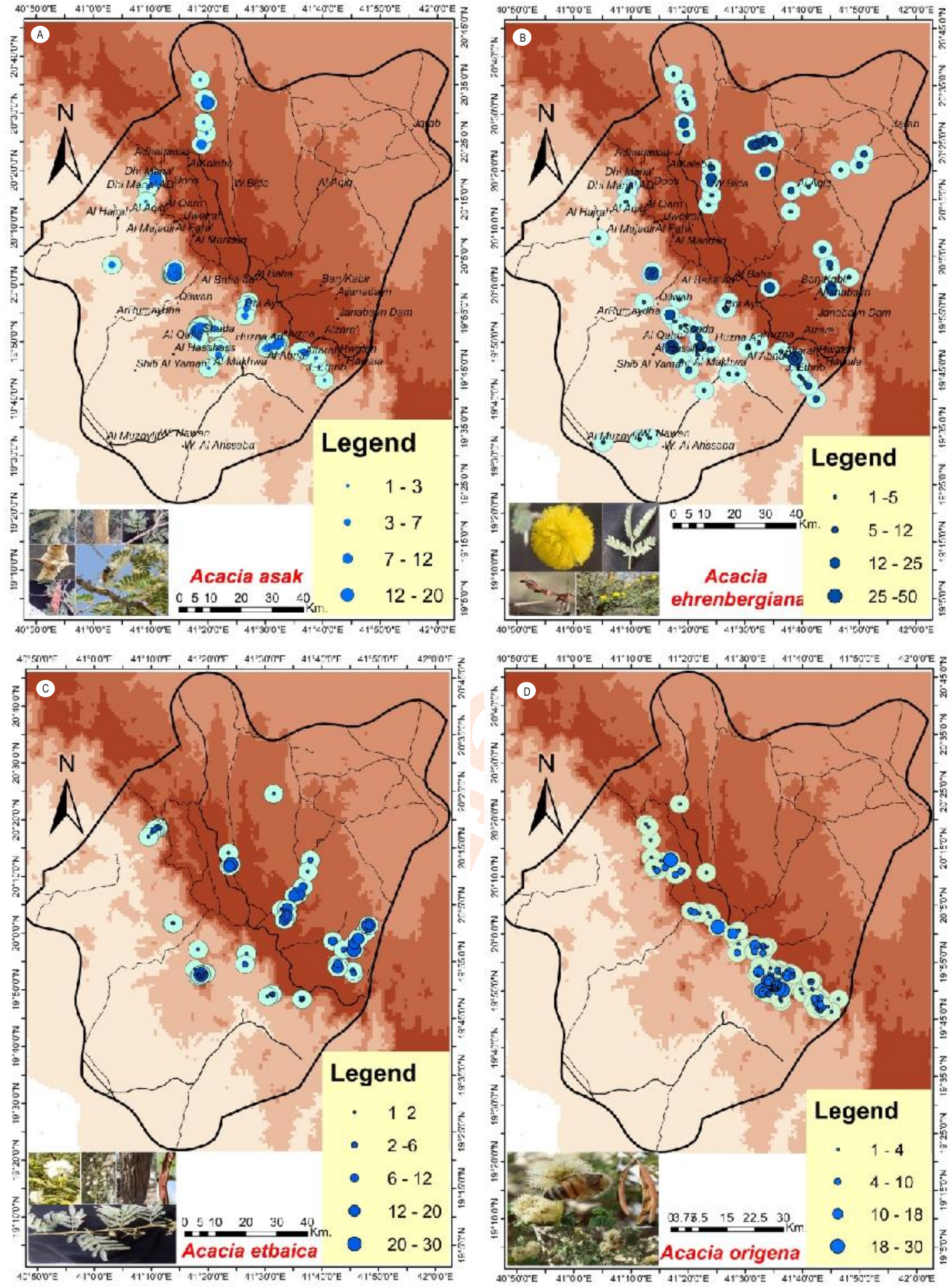

Fig. 3: Relative suitable apiaries radius maps of 9 major honey bee flora with their number of individual per quadrate. (A) Acacia asak: Al Abna, Huzna, Al Baha and Dhi Ayn descents at altitude lower than 1700 m., J. Shada and Al Baha-Tayf road; Blooming time: April to September; (B) Acacia ehrenbergiana Al Abna, Huzna, Al Baha and Dhi Ayn descents at altitude lower than 1000 m., J. Shada, Al Baha-Tayfroa, Al Rumaydhah, around Al Aqiq, WadiBida WadiNawan Blooming time: February-July; (C) Acacia etbaica Suitable Areas: Huzna, Al Baha and Dhi Ayn descents at altitude lower than 1150 m., Al Janabayn, J. Shada, Al Baha-Al Aqiqroad and around Al Aqiq. Blooming time: Sebtember-October; (D). Acacia origina Suitable Areas: High altitude areas, over 1700 m. asl, between Hawalah and South East to North Uweirah. 

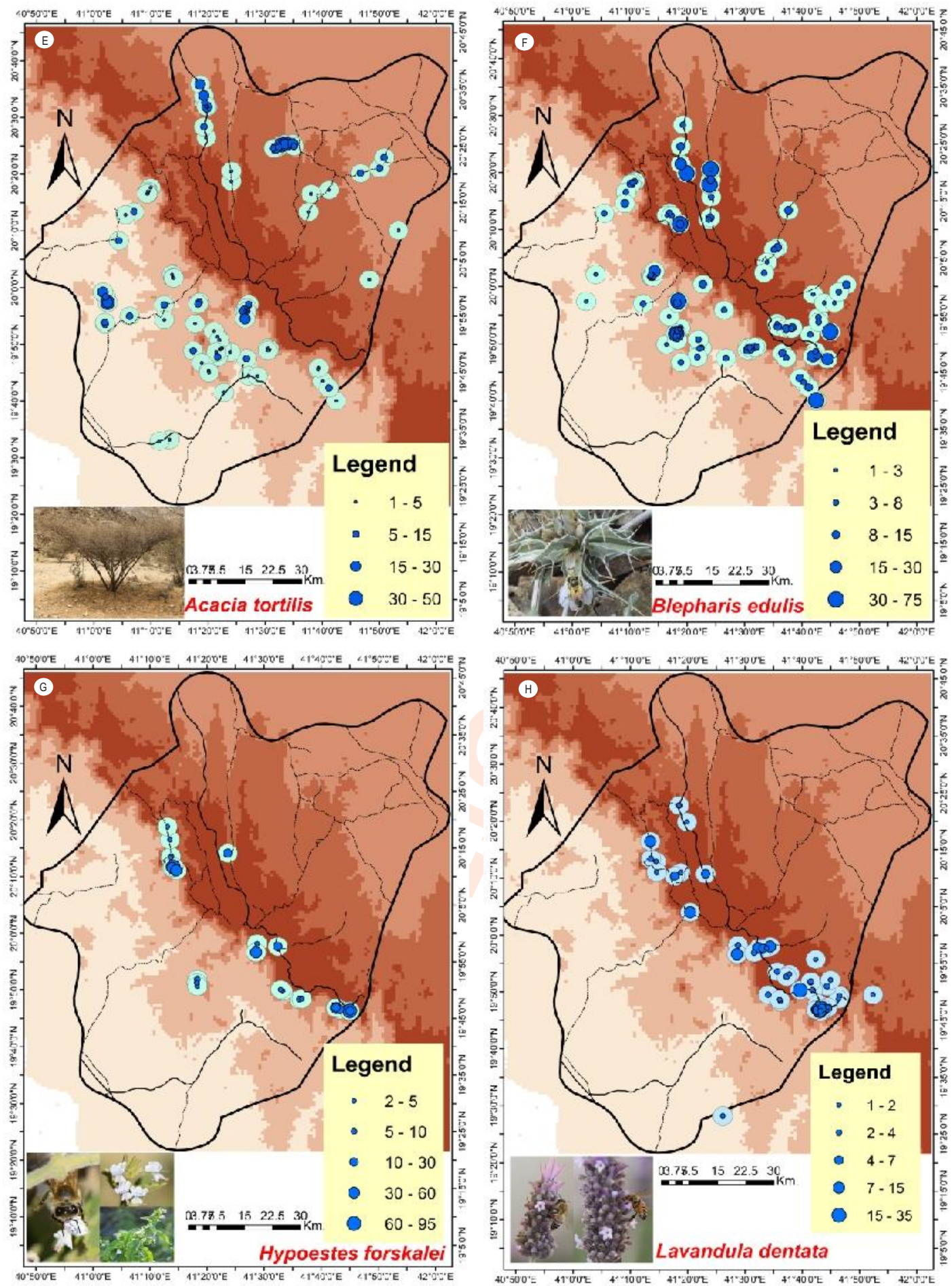

Fig. 3: Relative suitable apiaries radius maps of 9 major honey bee flora with their number of individual per quadrate. (E) Acacia tortilis : Suitable Areas: Al Abna, Huzna, Al Baha and Dhi Ayn descents at altitude lower than 1000 m., J. Shada, Al Baha-Tayfroa, Al Rumaydhah, around Al Aqiq, WadiBida and Wadi Nawan Blooming time: January -March; (F) Blepharis edulis Suitable Areas: Al Abna, Huzna, Al Baha and Dhi Ayn descents at altitude lower than 1000 m., Al Janabayn, Baljurashi, Hawala, J. Shada, Al Mandaq, WadiBida and Al Baha-Tayef road Blooming time: January to April and October to November; (G) Hypoestes forskolei Suitable Areas: High altitude areas, over $1400 \mathrm{~m}$. asl, Al Baha and Baljurashi, Hawala, Al mandaq, Owera and J. Shada Blooming time: January-April and September-December; $(\mathrm{H})$ Lavandula dentata Suitable Areas: High altitude areas, over $1800 \mathrm{~m}$. asl, between Hawala South East to North Umeira. Blooming time: February-May. 


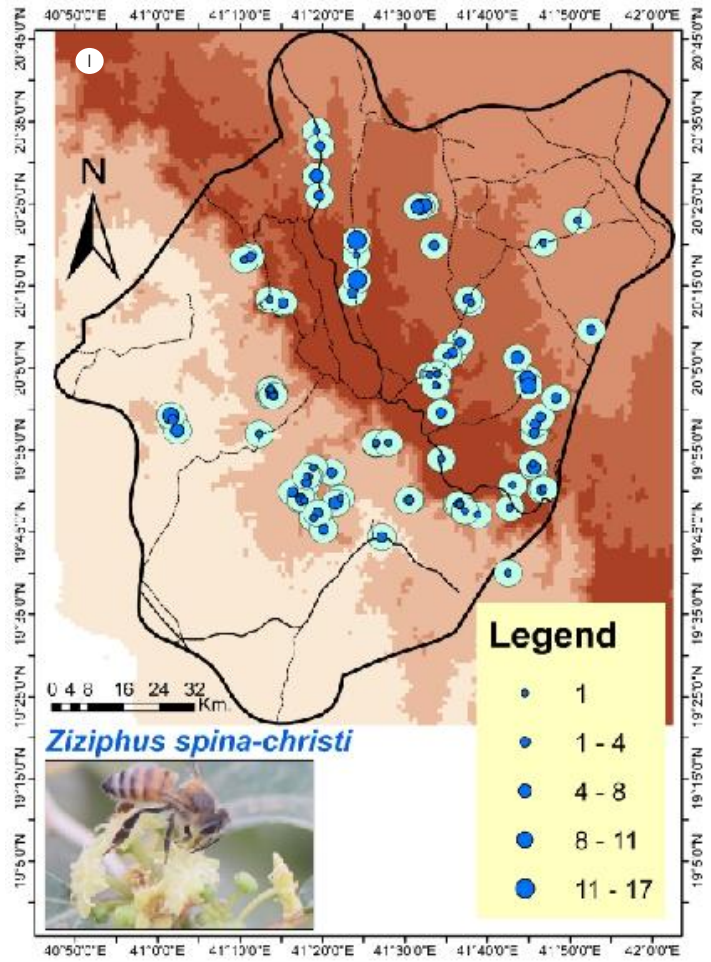

Fig. 3: Relative suitable apiaries radius maps of 9 major honey bee flora with their number ofindividual per quadrate. (I) Ziziphus spina-christi Suitable Areas: Wadis less than $1500 \mathrm{~m}$. West and less than $1800 \mathrm{~m}$. East such as Al Baha and Dhi Ayn descents, J. Shada, WadiBida, Al Baha-Al Aqiq road, Al Baha-Tayf road and Al Janabayn Blooming time: July-October. strong with other groups (Fig. 4). Association of $A$. asak with a steep slope and that $A$. etbaica with eastern aspect has been previously reported (Nuru et al., 2016b). The Canonical Correspondence Analysis revealed that altitude and rainfall were the most important variables for determining the distribution and also the association species and clear segregations were found among different groups. Similarly, Al-Aklabi et al. (2016) and AlKhulaidi et al. (2018) reported that altitude and rainfall are important factors for determining the distribution and association of species. Though 9 major honey bee plant species formed three distinct cluster groups (Fig. 4); it was obviously observed that overlapping of several bee plant species on the same habitat based on the suitability of the areas to support the growth of different species. Accordingly, in very poor habitats only 1-2 species per $10 \mathrm{sq}$. km (yellow mark) grow which account major parts (>60\%) of the study area. In relatively better habitats up to 4 -5 species per 10 sq. km (pink mark) or 5-6 species per 10 sq. km (red mark) were observed to grow, but they were distributed in very limited parts of the study area (Fig. 5). Relatively 2-3 species per site (blue mark) and 3-4 species per 10 sq. km (green mark) covered considerably large parts of the studied areas (Fig. 5).

Out of 204 bee plant species studied, only 10 were found important for honey production. Moreover, out of the first 13 bee plant species with top frequency percentages ( $\geq 20 \%$ ), only 5 of them were found to be a good source of honey. This is in agreement with Crane's (1990) report who indicated that only $1.6 \%$ of the world's honey plants are the source of major honey. In addition, the densities per hectare recorded for major honey source plants were relatively lower than non-major honey source plants. The low honey plant density per hectare of this study may

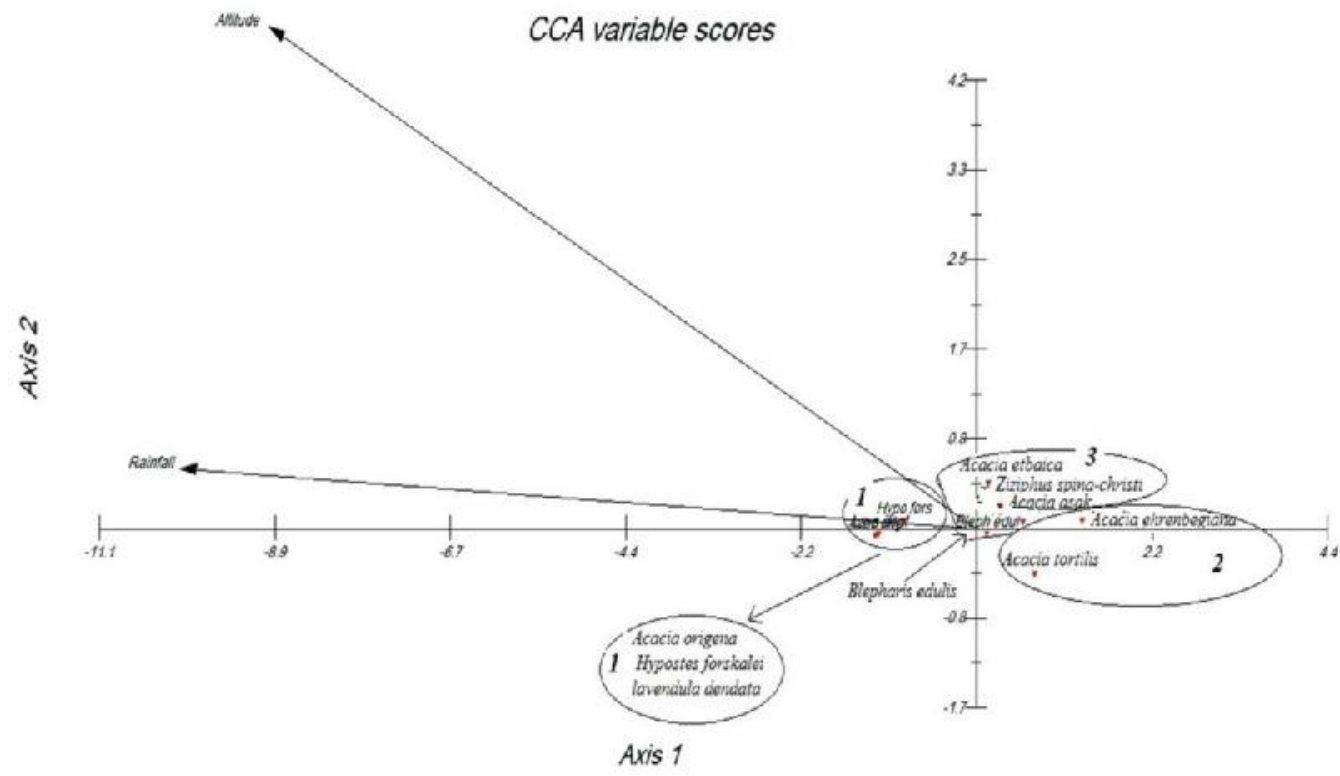

Fig. 4: Canonical Correspondence Analysis (CCA) ordination biplot of sampling points on main landforms (altitude) and environmental variables (rainfall). Arrows represent the environmental data and point in the direction of maximum change of the environmental variable across the diagram. 


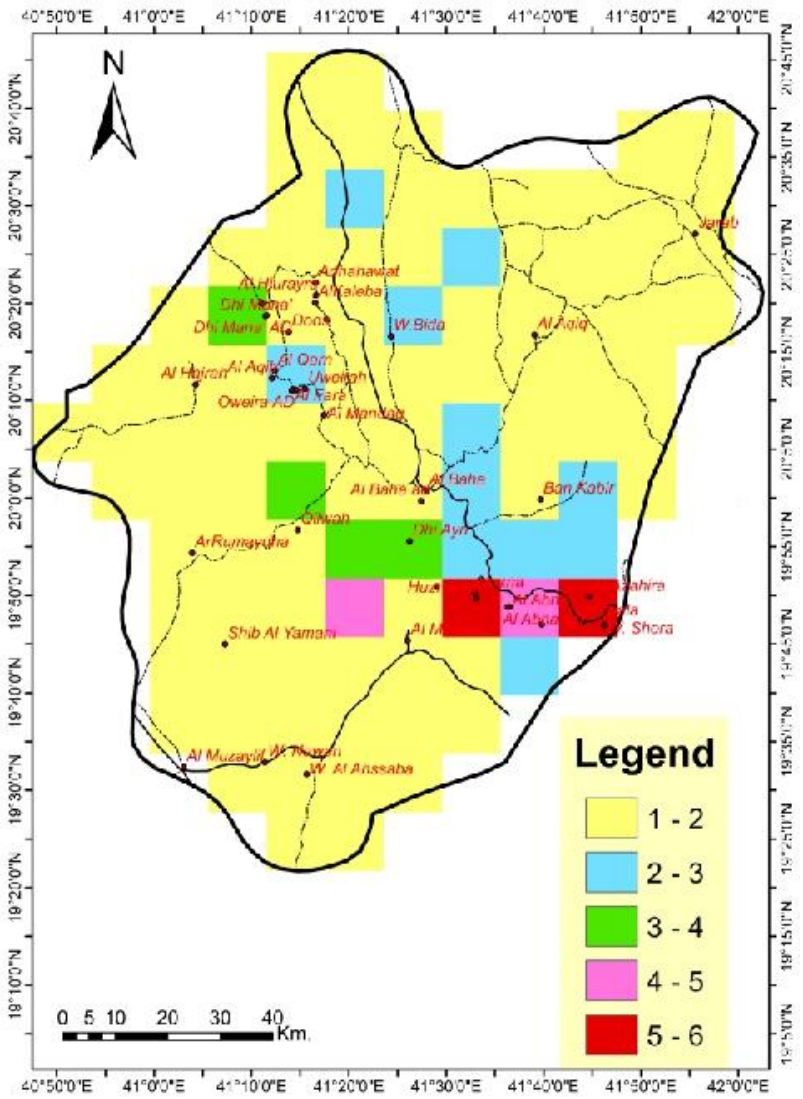

Fig. 5: Distribution of nine major honey plants.

indicate deforestation and decline of vegetation coverage in the region. The declining of forests and vegetation coverage as a result of extensive human activities and environmental factors have been well reported for the region (Batanouny, 1991; Dawson, 2007; Hall, etal., 2010).

On the other hand, frequency percentage and density of species may not be always important parameters to evaluate the value of species to bees and beekeeping. In this regard, besides frequency percentages and density per hectare; canopy area, flower density, nectar secretion dynamics and nectar sugar concentration would be useful parameters for determining the value of species for honey production as it has been reported by Nuru et al. (2015; 2016a). In the study area, it was noted that only perennials trees and shrubs are important sources of honey due to the fact that under limited rainfall conditions of the region, perennials with their deep roots can access groundwater and may survive dry seasons and produce nectar better than annuals. The wide range ecological adaptation and distribution of some of the bee plants (A. ehrenbergiana (Fig. 3A), A. tortilis (Fig. 3E), Blepharis edulis (Fig. 3F) and Ziziphusspina-christi (Fig. 3I)) in the region has created variations in flowering period between low and mid altitude plants of same species. Such phenomenon have created opportunities for beekeepers to have frequent honey harvesting within the same flowering season from the same species through migrating of their colonies from place to place. In the region, the presence of 2-9 times honey bee colonies migration/annum and subsequent honey harvesting following flowering of different honey source plants at different periods and ecologies have been well reported (Nuru et al., 2014). Based on the bee plant species diversity, areas that support more than two bee plant species can be considered as relatively more potential for beekeeping. Despite significant diversity of bee plant species, the vegetation cover, in general, and honey bee plant frequencies and densities in particular, are declining in the region. To sustain beekeeping and honey production, beekeepers and the government should pay attention towards large scale conservation and rehabilitation of degraded lands in general and bee forage landscapes in particular.

\section{Acknowledgments}

This Project was Funded by the National Plan for Science, Technology and Innovation (MAARIFAH), King Abdulaziz City for Science and Technology, Kingdom of Saudi Arabia, Award Number (13-AGR2118-02).

\section{References}

Akratanakul, P.: Beekeeping in Asia. FAO Agricultural Services Bulletin 68/4. Food and Agriculture Organisation of the United Nations, Rome (1990)

Al-Aklabi, A., A. Al-Khulaidi, H. Hussain and N. Al-Sagheer: Main vegetation types and plant species diversity along an altitudinal gradient of Al-Baha region, Saudi Arabia. Saudi J. Biol. Sci., 23, 687-697 (2016).

Al-Baggar, A. H.: Environmental distribution of eight major honey plants in Al-Baha region, Saudi Arabia. Int. J. Bio. Phar. All. Sci., 7, 400$414(2019)$

Al-Ghamdi,A., A. Zulail and N. Adgaba: Structure and performance of the retail outlets of honey in the Kingdom of Saudi Arabia. Food Nut. Sci., 5, 1168-1176 (2014)

Al-Ghamdi, A., N. Adgaba, A. Getachew and Y. Tadesse: New approach for determination of an optimum honeybee colony's carrying capacity based on productivity and nectar secretion potential of bee forage species. Saudi J. Biol. Sci., 23, 92-100 (2016).

Al-Khulaidi, A., N. Al-Sagheer, M. Darfaoui and S. Al-Ameri: Trees of Albaha region and surrounding areas. FAO and Ministry of Environment water and Agriculture, Riyadh, Saudi Arabia. (Arabic version) (2016)

Al-Khulaidi, A., N. Al-Sagheer, T. Turki and F. Filimban: Inventory of most rare and endangered plant species in Al-Baha region, Saudi Arabia. Int. J. Bio. Phar. All. Sci., 7, 443-460 (2018).

Al-Zandi, A., A. W. Al-Khulaidi and N. Al-Sagheer: Preliminary analysing of plant diversity of high altitude area of Al-Baha region, Saudi Arabia. Int. J. Adv. Res., 6, 412-426 (2018)

Amanda, E., D.E. Jamie, K.O. Michael and M.Z. Catherine: The benefits of pollen to honey bees. ENY152, UF/IFAS Extension, University of Florida, U.S.A. (2010).

Batanouny, K.H.: Vegetation of the Summan (Arabia): Pattern and process as affected by human impact and modern technology. In: Proceedings of $4^{\text {th }}$ International Rangeland Congress, Montpellier, France, 4, pp. 310-314 (1991).

Beekman, M. and F.L.W. Ratnieks: Long-range foraging by the honeybee, Apis mellifera L. Funct.I Ecol., 14, 490-496 (2000) 
Behera, L.K., A.A. Mehta and S.K. Sinha: Suitable bee flora availability for commercial apiculture during dearth period in the heavy rainfall zone of South Gujarat. Res J. Chem. Environ. Sci., 2, 65-68 (2014).

Beyene, G. and T.G. Hiwot: Feed resources of honeybees in Kewet District of Amhara, Ethiopia. J. Res. Develop. Manage., 7, 92-96 (2015).

Bhalchandra, W., R.K. Baviskar and T.B. Nikam: Diversity of nectariferous and polleniferous bee flora at Anjaneri and Dugarwadi hills of Western Ghats of Nasik district (M.S.) India. J. Entomol. Zool. Stud., 2, 244-249 (2014).

Crane, E.: Bees and Beekeeping: Science, Practice and World Resources. Heinemann Newnes, Oxford, pp. 614 (1990).

Dawson, T.P.: Potential impacts of climate change in the Arabian Peninsula. Proceedings of International Conference on Desertification. Kuwait, Inst. Sci. Res. (KISR), Kuwait (2007).

Dukku, U.H.: Identification of plants visited by the honeybee, Apis mellifera L. in the Sudan Savanna zone of northeastern Nigeria. African J. Plant Sci., 7, 273-284 (2013).

El-Juhany, L.I.: Forest degradation and potential rehabilitation in southwest SaudiArabia. Aust. J. BasicAppl. Sci., 3, 2677-2696 (2009).

Hall, M., S. Neale, T.M. Al-Abbasi and A.G. Miller: Arabia's tallest trees: Ecology, distribution, and conservation status of the regionally endangered tree species Mimusops laurifolia. Nord. J. Bot., 28, 240-245(2010).

Kumar, D., V. Sharma and U. Bharti: Floral inventory of wild honey bee forage. Int. J. Sci. Res., 5, 105-107 (2016).

Nuru A., A. Al-Ghamdi, R. Sammoud, A. Shenkute, Y. Tadesse, M.J. Ansari, D. Sharma and C. Hepburn: Determining spatio-temporal distribution of bee forage species of Al-Baha region based on ground inventorying supported with GIS applications and remote sensed satellite image analysis. Saudi J. Biol. Sci., 24, 1038-1044 (2017).

Nuru, A., A. Ahmed, T. Yilma, G. Awraris, M.A. Awad, J.A. Mohammad,
A.O. Ayman, A.M. Seifeldin and S.A. Abdulaziz: Nectar secretion dynamics and honey production potentials of some major honey source plant species of Saudi Arabia. Saudi J. Bio. Sci., 24, 180-191 (2017).

Nuru, A.: Prospects: Strategic development intervention for rapid improvement of beekeeping industry in Ethiopia. In: Proceedings of Apimondia International Symposium. Addis Ababa, Ethiopia. pp. 36-4911/30/18 (2018).

Nuru A., A. Ahmed,T. Yilma, G. Awraris, A. Anwar and J.A. Mohammed: Floral phenology, nectar secretion dynamics and honey production potentials of lavendula species ( $L$. dentata and $L$. pubescence) in south-western Saudi Arabia. J. Apic. Sci., 59, 135-144 (2015).

Nuru A., A. Ahmed, T. Yilma, G. Awraris and J.A. Mohammad: Pollination biology and spatio-temporal structuring of some major Acacia species (Leguminosae) in the Arabian Peninsula. Pak. J. Bot., 48, 1517-1526 (2016b).

Nuru, A., A. Al-Ghamid, A. Shenkut, M. Medani, R. Sammouda, M.J. Ansari and S. Radloff: Pollination ecology of Acacia ehrinbergiana (Hyne) and Acacia tortilis (Forssk.) Hayne, Leguminosae (Mimosoidae) dynamics of nectar secretion and their roles in honey production. J. Trop. Ecol., 57, 429-444 (2016a).

Nuru,A., G. Awraris, A. Shenkute, A. Al-Ghamdi, S. Ismaiel, S. Al-kahtani, Y. Tadesse, M.J. Ansari, W. Abebe and M.Q. Abdulaziz: Socioeconomic analysis of beekeeping and determinants of box hive technology adoption in the Kingdom of Saudi Arabia. Pakistani J. Anim. Plant. Sci., 24, 1876-1884 (2014).

Sammouda, R., A. Touir, F. Saeed, M. Nuru and A. Al-Ghammidi: Spatial distribution of honeybee forage based on color satellite image segmenting using K-Mean clustering. J. Mult. Process. Techno., 4, 39-46 (2013). 